Sciendo

10.2478/abcsj-2020-0014

\title{
The Destruction of Nationalism in Twenty-First Century Canadian Apocalyptic Fiction
}

\author{
MATTHEW CORMIER \\ University of Alberta, Canada
}

\begin{abstract}
This article argues that, since the turn of the twenty-first century, fiction in Canada - whether by English-Canadian, Québécois, or Indigenous writers - has seen a re-emergence in the apocalyptic genre. While apocalyptic fiction also gained critical attention during the twentieth century, this initial wave was tied to disenfranchised, marginalized figures, excluded as failures in their attempts to reach a promised land. As a result, fiction at that time - and perhaps equally so in the divided English-Canadian and Québécois canons - was chiefly a (post)colonial, nationalist project. Yet, apocalyptic fiction in Canada since 2000 has drastically changed. 9/11, rapid technological advancements, a growing climate crisis, the Truth and Reconciliation Commission: these changes have all marked the fictions of Canada in terms of futurities. This article thus examines three novels English-Canadian novelist Emily St. John Mandel's Station Eleven (2014), Indigenous writer Thomas King's The Back of the Turtle (2014), and Québécois author Nicolas Dickner's Apocalypse for Beginners (2010) - to discuss the ways in which they work to bring about the destruction of nationalism in Canada through the apocalyptic genre and affectivity to envision new futures.
\end{abstract}

Keywords: apocalyptic genre, English-Canadian fiction, Québécois fiction, Indigenous fiction, nationalism, globalization, Emily St. John Mandel, Thomas King, Nicolas Dickner

\section{Introduction}

The apocalyptic genre has cyclically pervaded writing in Canada since colonial times, when explorers crossed the Atlantic Ocean to settle a land ripe with resources and opportunities. While a common narrative element 
of the apocalypse is to leave an old, ruined world behind in exchange for a new, better one, this latter utopic promise never fully actualized: as Marlene Goldman explains in Rewriting Apocalypse in Canadian Fiction, this failed promise created "an ironic tension" in which "Canadian exploration more often invoked apocalyptic visions of hell than of paradise" (3). Indeed, literary classics on Canada's pioneer period, such as Susanna Moodie's Roughing It in the Bush and Louis Hémon's Maria Chapdelaine (1913), speak to this disillusionment. ${ }^{i}$ Moodie's work in particular, which tells of her emigration to Canada and subsequent difficulties with settling land, draws attention to the failed fulfillment of the apocalyptic prophecy: when arriving in cholera-laden Montreal, for example, she observes that

[the] sullen toll of the death-bell, the exposure of ready-made coffins in the undertakers' windows, and the oft-recurring notice placarded on the walls, of funerals furnished at such and such a place, at cheapest rate and shortest notice, painfully reminded us, at every turning of the street, that death was everywhere - perhaps lurking in our very path; we felt no desire to examine the beauties of the place. (23)

Instead of finding Eden, these immigrants discovered a cholera-plagued hellscape in which they had to adapt to survive. In fact, Margaret Atwood would later argue in her 1972 work of criticism, Survival: A Thematic Guide to Canadian Literature, that this colonialist, survivalist attitude became central to Canada's literary canon and to the founding of a truly distinct, national Canadian literature. Although repeatedly criticized by scholars such as Robin Mathews, Frank Daveys, and Joseph Pivato for its reductive view of Canadian literature, Atwood's text, in which she claims that "[the] central symbol of Canada - and this is based on numerous instances of its occurrence in both English and French Canadian literature - is undoubtedly Survival, la Survivance" (32), has left a definitive mark in the national literary imaginary of Canada. ${ }^{\text {ii }}$ Criticism of Survival aside and as Goldman diligently maintains in Rewriting Apocalypse in Canadian Fiction - the postmodernist novels in Canada from the 1980s and 1990s reimagined the apocalyptic genre to complicate its earlier, nationalist tendencies, and, as this article argues, twenty-first century apocalyptic fiction in Canada signals the destruction of nationalism 
altogether, dispelling borders and opening up narratives to a depoliticized civilization.

Unlike Atwood, who prefers to speak of the apocalyptic genre in Canada in terms of survival and victimhood, Goldman works with the tension between the apocalyptic elect and the non-elect, those who suffer from the trauma of having been "barred from paradise" (5). "In contrast to the traditional biblical apocalypse," Goldman explains, "Canadian fiction refuses to celebrate the destruction of evil and the creation of a new, heavenly world. Instead, these works highlight the devastation wrought by apocalyptic thinking on those accorded the role of the non-elect" (5). Goldman's approach is somewhat more nuanced than Atwood's, as it focuses on socioeconomic disparities rather than symbolic binaries, and therefore creates space to include multicultural and Indigenous voices who complicate or explicitly contest nationalism in apocalyptic allegories; moreover, the objects of her study stem from a mature period in Canadian literature. Post-Second World War pessimism and subsequent Cold War era paranoia, coupled with the growth of literary postmodernism - which, according to acclaimed theorist Linda Hutcheon in "The Politics of Representation," promoted "the story-telling of the non-combatants or even the losers" (38) and in a fragmented, non-linear style - did much to cast doubt on nationalism in Canada. This time also marks a transition from the right-leaning image of "grassroots Canadians" - settler colonials - that so often appeared in the texts studied by Atwood to the left-leaning validation of immigrant and Indigenous experiences in the country as a colonized territory. As a result, marginalized voices such as those studied by Goldman, including Thomas King's Green Grass, Running Water (1993) and Joy Kogawa's Obasan (1981), had the space and formal framework in place to criticize Canada's colonial history as well as its treatment of immigrants. Goldman's reading of King, whose "fictions specifically link apocalypse to the disastrous clash between the settlerinvader society and North American Native People" (104), is particularly pertinent with respect to the present work. She goes on to explain that, in the novel, King "shows how the book, adopted and adapted by Native writers, can function as a communal map that offers an alternative to apocalypse's individualistic, future-oriented map" and "elaborates on the 
intriguing connection between fiction-making and cartography" (104). As this article will later discuss, King continues this work in The Back of the Turtle, but the connection also applies to the other texts as well, which all work to dispel national borders in some way, borders which represent Western colonization and capitalism. The apocalypses in these novels are thus meant to re-imagine "individualistic maps" - or perhaps national ones - as communal cartographies that transcend sociocultural and geographical division.

Thus, Goldman's study not only shows the ways in which these novels "[prompt] readers to consider how the myth of apocalypse shaped earlier moments in Canadian history" (164), but also how they stand as "fundamental [rejections] of apocalypse's fascist promise of perfection and its faith in a future predicated on the violent destruction of the early world" (162). This promise, I argue, had also lent itself to the utopic pledge of nationalism, and if apocalyptic novels in Canada criticized this pledge during the latter half of the twentieth century, writers in the twenty-first century have outright condemned it with their takes on the genre, perhaps heeding Slavoj Žižek's warning in Living in the End Times that

the global capitalist system is approaching an apocalyptic zero-point. Its "four riders of the apocalypse" are comprised by the ecological crisis, the consequences of the biogenetic revolution, imbalances within the system itself (problems with intellectual property; forthcoming struggles over raw materials, food and water), and the explosive growth of social divisions and exclusions. $(\mathrm{x})$

Namely, Emily St. John Mandel's Station Eleven, King's most recent novel, The Back of the Turtle, and Nicolas Dickner's Apocalypse for Beginners all tackle issues related to this global capitalist system, effectively eliminating the affective power of nationalist ideologies and interests. Melissa Gregg and Gregory J. Seigworth describe affect in The Affect Theory Reader as "in the midst of inbetween-ness: in the capacities to act and be acted upon [...] as well as the passage (and the duration of passage) of forces or intensities" (1). Affective power, they go on to argue, "is found in those intensities that pass body to body (human, nonhuman, part-body, and otherwise), in those resonances that circulate 
about, between, and sometimes stick to bodies and worlds, and in the very passages or variations between these intensities and resonances themselves" (1). It is precisely the power of affect to pass in-between, whether in terms of borders, generations, classes, that allows it to dismantle these very structures over the course of time.

The three texts in question understand the cyclical nature of the apocalypse in particular and its various, destructive guises: as religious studies scholar Tina Pippin has theorized, "[every] apocalypse is a sequel. A sequel is a work which follows another work and can be complete and seen in relation to the former and what follows it. The story becomes the neverending story, in ever-evolving renditions" (1). Apocalyptic history, in particular in these narratives, tends to repeat itself in ways that ignore national borders. In Station Eleven, when a pandemic sweeps across the world, it disregards national borders. Recalling the events surrounding the SARS outbreak and anticipating those encompassing the COVID-19 pandemic, the "Georgian Flu" from St. John Mandel's novel decimates a civilization that had not learned its lessons from past experiences on a global scale within a month of its appearance: "No more pharmaceuticals. No more certainty of surviving a scratch on one's hand [...] No more countries, all borders unmanned" (31). The apocalyptic pandemic in Station Eleven - it, too, being a sequel - thus also collapses national borders, destroying the idea of countries and instead promoting humanity as a global community determined to build a new world from the ashes of the old one. The Back of the Turtle, for its part, focuses on ecological threats in the face of capitalism; in one exchange from the novel, Winter, an executive assistant, presents a list to Dorian, the CEO of an energy company, human-made disasters or testing sites that have had destructive consequences on the environment, as documented by one of the company's scientists:

"Chernobyl. Idaho Falls. Chalk River." Dorian read the names on the screen. "Pine Ridge, South Dakota?"

"It's an Indian reservation," said Winter. "It was used as a bombing range during World War II."

"Rokkasho and Lanyu?"

"Nuclear and biological waste dumps." 
"Renaissance Island.” Dorian's face softened, as though he had run into an old friend. "The Russian anthrax facility." (23)

The list evidently crosses national borders, even oceans and continents, demonstrating the apocalyptic cycle of humanity's influence on the environment, especially over the past century. It speaks to Goldman's argument regarding King's Indigenous perspective and ability to expand a "communal map" that takes away from apocalypse's individualism. Finally, Apocalypse for Beginners features Hope Randall, the youngest descendent of a family whose members have endured visions of the apocalypse - visions that never came to be - for generations: "Indeed, the Randall family tree could be used in a course on the history of psychiatry in North America over the past one hundred and fifty years" (9). The apocalyptic cycle tormented the Randalls - and Hope in her quest to end it - all the way from France to Canada during colonial times, and then to the United States and finally Japan at the turn of the twentieth century, showing that the apocalypse is a global rather than national affair. Yet, while the narratives in these apocalyptic novels literally cross or dispel borders, the affects that they circulate work to create communal maps in various forms as well.

\section{"Survival Is Insufficient": Civilization in Station Eleven}

Station Eleven implies the anti-nationalist aftermath of the apocalypse in a number of ways through several of its stories and often in a positive, optimistic light. The geography of the narrative - just as the pandemic at its heart - spans numerous borders, connecting characters from Moscow to Paris, Malaysia to Canada, and Australia to the United States. One of the novel's central plot lines follows the Travelling Symphony, which goes from settlement to settlement and performs Shakespeare and music in the post-apocalyptic world, often crossing what was once the border between Canada and the United States between Ontario and Michigan; another account chronicles the life of a group of people living out of an airport, once a prominent symbol of national defence, especially following 9-11, as well as a globalist, liminal space between nations, but now a purgatory-turned-haven for its residents. Fifteen years after the pandemic, 
the airport even developed a small school in the former First-Class lounge to educate those born after the apocalyptic event, where they learned that, before the Georgian Flu, "no place on Earth [...] was too far to get to" (262). In fact, and in disbelief,

[the students] were told about the Internet, how it was everywhere and connected everything, how it was us. They were shown maps and globes, the lines of the borders that the Internet has transcended. This is the yellow land of mass in the shape of a mitten; this pin here on the wall is Severn City. That was Chicago. That was Detroit. The children understood dots on maps - here - but even the teenagers were confused by the lines. There had been countries, and borders. It was hard to explain. (262)

As the now-meaningless dots and lines suggest, if globalization - the mighty Internet that "was us" - that had already outstripped nationalism could be conquered by this pandemic, then nations did not stand a chance. In this new world, St. John Mandel's novel valorizes smaller, tight-knit communities and connections that are no longer desensitized by the alienating effect of nationalism, globalism, and the influx of information made possible by the Internet and constant access to it; the students are "confused by the lines" not only because of their incomprehensible past geographical significance, but also due to the apparent strangeness of the concepts of nationalism and globalism to them in general.

Furthermore, just as the novel applies the idea of transcendence to former national borders, so too is it applied to those humanist values that persist in the post-apocalyptic landscape. Leaning heavily on the Star Trek-based mantra of "survival is insufficient," Station Eleven suggests that to survive the apocalypse is not enough, and instead turns its focus towards what should prevail in civilization's memory as unifying items: art and artifacts that show humanity's most elegant accomplishments and purpose. The persistence and resilience of art and purpose is a recurring theme in the novel, from the Travelling Symphony's proliferation of music and Shakespeare's plays to the importance of the eponymous Station Eleven comic books that protagonist Kirsten carries around and that tie her to other characters that she meets throughout the narrative, the return of the printed newspaper to the spiritual magnetism of the New 
Testament. A conversation between another protagonist, Jeevan, and his paraplegic brother, Frank, reveals the tension at the core of the novel:

“After I was shot, when they told me I wouldn't walk again and I was lying in the hospital, I spent a lot of time thinking about civilization. What it means and what I value in it. I remember thinking that I never wanted to see a war zone again, as long as I live. I still don't."

"There's still a world out there," Jeevan said, "outside this apartment."

"I think there's just survival out there, Jeevan. I think you go out there and try to survive." (183)

Shortly thereafter, Frank takes his own life, allowing Jeevan to leave the apartment by himself; little did Frank know at the time that Jeevan would survive and even thrive by finding value in the post-apocalyptic civilization, finding a partner, having a son (named after his deceased brother), and helping others with medical treatment due to his training as a paramedic. In this borderless world, with credentials and regulations no longer a currency, Jeevan flourished and found purpose in his life beyond mere survival: "The world was a string of settlements now and the settlements were all that mattered, the land itself no longer had a name" (269). In St. John Mandel's universe, then, the apocalypse allows individuals to transcend survival rather than resolve themselves to it as Atwood suggested of earlier Canadian literary works. In fact, the novel promotes a counter to the issues that Žižek lays out in terms of restoring balance and equality in this new society, free from national and global capitalist greed, by returning to a more generous, trade-based community. More than survival, the core objective in Station Eleven appears to be to preserve the generous parts of civilization and the simple aesthetics that defined it. At the airport, a former scholar named Clark, "when the airport had fewer people, had worked all day at the details of survival" (258). Later, however, by Year Fifteen, Clark had developed and maintained the Museum of Civilization up in the airport's Skymiles Lounge. "There seemed to be a limitless number of objects in the world that had no practical use but that people wanted to preserve," Clark had observed, and, similarly to Jeevan, he had found a purpose in this post-apocalyptic world: to preserve civilization (258). 


\section{A Return to Bimaadiziwin in The Back of the Turtle}

For Indigenous peoples in Canada and their civilizations, however, the apocalypse has no need to be fictionalized; it is already a recurring reality due to ongoing colonialism. As most critics agree and Grace L. Dillon specifies, "Native Apocalypse is really that state of imbalance, often perpetuated by 'terminal creeds' [....] Imbalance further implies a state of extremes, but within those extremes lies a middle ground and the seeds of bimaadiziwin, the state of balance, one of difference and provisionality, a condition of resistance and survival" (9). ${ }^{\text {iii }}$ The global capitalist system in which colonialism began and has since prospered threatened the bimaadiziwin inherent in Indigenous civilizations, a threat that is never fully acknowledged by the capitalist powers but is always looming. King's The Back of the Turtle deals with the colonial, global capitalist, and apocalyptic threats to the environment in particular that are the competitive energy and agriculture sectors from an Indigenous perspective. The novel features Dorian Asher as the head of Domidion, a leading multinational corporation with interests in oil as well as agribusiness. In its quest for globalism and capitalism, Domidion is responsible for a number of environmental disasters, including that which wiped out Samaritan Bay, the beach of Smoke River Reserve in British Columbia; a new agriculture product, GreenSweep, was released accidentally into the water system by Domidion employees, effectively killing the wildlife and ecosystem in general.

The narrative has Dorian searching for Dr. Gabriel Quinn, lead scientist and inventor of GreenSweep, who has left the company - without the CEO's knowledge, Gabriel has returned home, which incidentally happens to be Smoke River Reserve. Amid his search for Gabriel, Domidion's leader must deal with their latest disaster in the form of an oil spill in the Athabasca River in Alberta. He continuously attempts to frame the issue as one of national interest; preparing for an interview with Manisha Khan on the investigative television show, En Garde, he steels his answers for the anticipated questions: 
Athabasca River? Tragedy.

Oil extraction? National priority.

Safety protocols? The best in the industry.

Environmental damage? Minimal

Legal liability? An unfortunate accident. (422)

Even while trying to rally oil extraction around a nationalist cause, however, Dorian cannot escape the global ramifications of his company's latest apocalyptic disaster, even contradicting himself on the matter when he insinuates during the interview that the Zebras, a global, eco-terrorist group, might be responsible for the spill (425). When pressed on the disaster by Manisha, Dorian further conflates nationalism and globalism, capitalism and security, responding: “The modern world runs on energy, Manisha. Domidion can't change that. The spills are unfortunate, but our first priority has to be the security of the nation and the protection of our children's future" (425). The strategy here is that, by masking Domidion's global capitalist objectives behind a sense of national duty or priority, Dorian can both justify his company's actions as well as deflect attention away from its financial goals. His nationalist plight is not new and certainly not as a recurring affective ploy in apocalyptic sequels: one needs to look no further than the example of $9 / 11$ and its aftermath, in which the United States patriotized the invasion of Iraq to justify its baseless mission to find weapons of mass destruction that were never there. In that case, as Brian Massumi argues in "The Future Birth of the Affective Fact," veiling the political action behind a looming threat to national security affected the public's perception because "[the] threat will have been real for all eternity... Whether the danger was existent or not, the menace was felt in the form of fear" (53-54).

In The Back of the Turtle's apocalyptic imagining, however, the spell of nationalism is broken by the global repercussions of Domidion's capitalist negligence. While Dorian attempts to quash the Athabasca River crisis and deal with the Zebras, a company ship filled with toxic waste, the Anguis, remains lost at sea. With the disposal of these materials in the ocean prohibited by Canada soon after its departure, and international ports refusing to take in the boat, the Anguis was in the Caribbean when a storm hit it, and Domidion lost contact with the crew and the barge had 
vanished. Understandably, Dorian wants this apocalyptic environmental disaster to affect others rather than himself, far from home:

The only thing that had really mattered was that, when the barge broke apart and sank with her load of biologicals, she be as far away from Canada and the U.S. as possible. Off the coast of Cuba, thought that was a little too close to Florida and the Gulf. Argentina or Chile. Or any of the other Central and South American countries that had not supported North America's trade and peace initiatives. (20)

Yet, Dorian cannot escape the threat of the Anguis. The ship reaches the shore of Samaritan Bay at the Smoke River Reserve, of all places, where Gabriel awaits it on the beach. Gabriel, his friends, and the Taiwanese crew that had survived sing and push the Anguis in unison until waves begin to hit it with force; the seventh wave, like the apocalyptic seventh seal, breaks the ship's hold on the shore, and it disappears back into the fog of the ocean (499-500). Thus, while Gabriel - whose name evokes the guardian archangel - protects Smoke River Reserve from another apocalyptic disaster, the Anguis and its deathly cargo returns to the open sea. Later, after the barge's close encounter with a cruise ship, Dorian learns that it is headed for the Gulf of St. Lawrence, "coming home" (515). The ship's toxic waste is certainly a global apocalyptic threat to the environment, having skirted the shores of a number of countries and drifted across two oceans; however, in an ironic twist, it will return to ruin the capitalist greed that created it.

\section{Apocalypse for Beginners and the Futurity of Threat}

If the Anguis and its floating apocalypse is to come in King's narrative, meanwhile, the same reckoning cannot be ensured with any seriousness in Dickner's Apocalypse for Beginners, since the novel repeatedly undermines the apocalypse's deterministic nature. As Jacques Derrida asserts in his essay, "On a Newly Risen Apocalyptic Tone in Philosophy," the prophetic essence of the apocalypse is self-fulfilling, resulting in "the apocalypse as sending of the apocalypse, the apocalypse that sends itself" (155). Of course, this apocalyptic predetermination is at the heart of many 
national defence attitudes, and Massumi's argument with respect to the futurity of threat once again holds true:

Self-renewing menace potential is the future reality of threat. It could not be more real. Its run of futurity contains so much more, potentially, than anything that has already actually happened. Threat is not real in spite of its nonexistence. It is superlatively real, because of it. (53)

The affective power of this looming apocalypse to feel real has caused humanity - and, in particular, nations - much grief throughout history, and Apocalypse for Beginners criticizes this nationalist attitude, especially in the context of the latter half of the twentieth century, in its own lighthearted way. The Randall family's cyclical apocalyptic curse, and Hope's resignation to it, is an evident example of this criticism; however, the recurring commentary on the Second World War and the subsequent Cold War represents an even more scathing, if humoristic, indictment of nationalism in the face of the imminent apocalypse.

With its core narrative arc beginning in the summer of 1989, Apocalypse for Beginners criticizes the continuation of the nationalist shoring up during the Cold War in the face of a perceived future threat by drawing parallels to North-American bunker mentality. Hope's mother, for example, hoards non-perishable food items in anticipation of having to hunker down in the basements of bungalows at the coming of the apocalypse: "sacks of flour, bags of ramen, containers full of water or cooking oil, canned food of every description" (6). Regarding shelter, Hope later explains to her friend, Mickey, while they are talking in his basement, adequately nicknamed "the Bunker," that:

Previously, houses had cellars, crypts, underground rooms, crawl spaces or secret vaults for storing Kalashnikovs. But the basement of a North American bungalow is different. It's insulated, heated, furnished, equipped with beds, freezers, cold-storage rooms, a television, a telephone and board games $[\ldots]$. The modern basement appeared during the Cold War. It's the product of a civilization obsessed with its future [...]. (37)

This paranoid, bunker mentality of preparedness is due in large part to the broader national fear of imminent annihilation in western countries from the 1950s onward, chiefly inspired by the United States' "enacted 
simulations of nuclear attack in an elaborate national socio-drama," as Guy Oakes called them (qtd. in Davis 2). The bunker mentality as it manifests itself in Dickner's novel shows how, as Tracy C. Davis asserts in Stages of Emergency: Cold War Nuclear Civil Defense, "these [western] nations ... [sought] to involve the populace in their own defense and plan for the preservation of governance against the overwhelming odds of surviving massive nuclear attack" (3). Yet, while this preoccupation with sheltering oneself from potential foreign attacks pervades Apocalypse for Beginners, so does the novel deride the paranoia. Writing an essay on the predicted end of the Cold War, for example, Hope insists that

instead of the atomic bomb we would soon start living in fear of industrial obsolescence of the USSR, as illustrated by the Chernobyl disaster. This new peril would be far greater than the H-bomb; it would be a selfdestructive device beyond anyone's control, a time bomb plugged into the very heart of Imperium Sovieticum. (48)

In this argument, nationalist ideology and systems are their own worst afflictions; their stalling industrial complex to blame for their inevitable downfall. As Hope later sardonically quips: "The UN inspectors can say what they like, the fact remains that the bungalow is the primary weapon of mass destruction invented during the Cold War" (229).

Additionally, like St. John Mandel and King's novels, Apocalypse for Beginners also repeatedly shows a fascination with perspectives on civilization and its ties to the nation, albeit with a more humorous approach than these other narratives. Often, Dickner opts for small ironies that subdue the gravity of such conceptions: for instance, Mickey explains that, with respect to his family's generational materials company, “concrete wasn't just a business; it was a matter of civilization, a mission to be passed on from father to son. We were builders of worlds" (41); shortly thereafter, he watches the collapse of the Berlin Wall, and along with it a national, global, and ideological divide in civilization, noting how "it was toppling over, and with mind-boggling ease. So a nudge from a bulldozer is all it took to dispose of this shameful structure?" (44). Yet, at other times, the novel points to the cyclical whims of nations and 
civilization, reading the signs that oscillate in ambiguity between optimistic and apocalyptic. In the weeks following the collapse of the Berlin Wall, Mickey continues to watch the construction around it, observing that "[nothing] looked more like the end of the world than the beginning of another" (64). This ambiguity persists for a time, as Mickey notes that "[at] times the apocalypse seemed very near. At other times, it seemed far, far away" (118). Apocalypses, however, come in waves, and soon thereafter, Hope signals to Mickey a report of another - nudged between mundane news - that is about to arrive:

Set in a small box between the weather and the winning Mini-Loto numbers was an item announcing the Iraqi invasion of Kuwait and the ensuing wrath of the Most Holy United States of America, whose craving for petroleum was unquenchable. A prelude to all the nastiness to come. Details on page 47.

So much for our return to civilization. (123-4)

Evidently, while the news clipping refers to the Gulf War at the beginning of the 1990s, it also anticipates later apocalyptic events at the turn of the twentieth century involving nationalist and global capitalist endeavours in terms of 9/11 and its aftermath, of which Mickey will not yet know by the end of the narrative. Interestingly enough, while he acknowledges that "our civilization was evolving, but not necessarily in the right direction" (202), at the end of the novel, Mickey appears to be fully optimistic as he sets out for Japan to meet Hope: "Things were much better now that the end of the world was behind us" (254). The apocalypse might be a sequel, but its future iteration has lost its hold on Mickey in the face of a reunion with Hope, literally and figuratively.

\section{Conclusions}

So, what do Station Eleven, The Back of the Turtle, and Apocalypse for Beginners - novels from three different cultural backgrounds in Canada share as critical insights into the apocalyptic twenty-first century? It would appear that each of these texts is wary of the influential potential of futurity, in particular; like in the biblical apocalypse, an anticipated or prophesied future has the power to affectively shape or inform the present, 
and not always "in the right direction," as Mickey points out. Apocalyptic affects, though not named as such, have already been theorized in terms of more personal, scaled down relationships to people or objects. ${ }^{\text {iv }}$ Sara Ahmed's Promise of Happiness and Lauren Berlant's Cruel Optimism are prime examples of scholarship on the halting impacts of futurities on marginalized presents. Ahmed, for instance, asserts that:

The history of happiness can be thought of as a history of associations. In wishing for happiness we wish to be associated with happiness, which means to be associated with its associations. The very promise that happiness is what you get for having the right associations might be how we are directed toward certain things. (2)

While happiness for Ahmed appears to be a ubiquitous, yet unidentifiable state, and its pursuit as a dangerous imperative, Berlant sees the harmful affective repercussions of optimism as constructed emotional relations:

A relation of cruel optimism exists when something you desire is actually an obstacle to your flourishing. It might involve food, or a kind of love; it might be a fantasy of the good life, or a political project. It might rest on something simpler, too, like a new habit that promises to induce in you an improved way of being. These kinds of optimistic relation are not inherently cruel. They become cruel only when the object that draws your attachment actively impedes the aim that brought you to it initially. (1)

These problematic futures, happiness and optimism, that determine the present in terms of relationships appear repeatedly in these novels on the personal scale: for instance, take Jeevan's narrative with his brother and subsequent, post-apocalyptic marriage in Station Eleven, Gabriel's relationship with his home, the Smoke River Reserve, which he unintentionally ruined in The Back of the Turtle, or even Mickey's at times toxic attachment to Hope in Apocalypse for Beginners. These characters all live in precarity in the face of investments in potentially threatening futures; only through a certain symbolic revelation - which is the meaning of the Greek apokalupsis, for apocalypse - are these characters able to transcend their respective personal purgatories brought on by their hopeful attachments: Jeevan by allowing his brother to sacrifice himself, Gabriel by pushing the Anguis away from the Smoke 
River Reserve's shore, and Mickey by flying off to Japan to find Hope after learning that she'd lived past her date for the end of the world.

Yet, these novels are concerned with broader concepts as well, especially the perceived future's impact on civilization, which inherently comprise understandings of nations and nationalism in the global capitalist system. In fact, these texts appear to suggest that, in order for civilization to prosper in its various forms, the apocalyptic destruction of nation states and interests must come to pass, signaling the death of nationalism. Most of the events that could be considered apocalyptic, on different scales, of Canada's twenty-first century thus far have, in some way been tied to national intrigue, and these have been fictionalized in these novels: the SARS pandemic of 2003 in Toronto, one of the hardest hit epicentres in the world; the history of oil spills in Alberta and their ongoing issues since the turn of the century, even as Canada seeks to approve new pipelines; continued Canadian involvement in wars overseas, from the Gulf War to the decades-long War in Afghanistan. These events have also been used, narrativized, by nations to affectively play on the fear of future threats, usually from foreign countries: immigration and racism; the nation's place in the global economy; offence as pre-emptive defence against foreign attacks. As Massumi shows with respect to the United States' response to $9 / 11$, affect can be harvested as power in times of crisis and chaos. In "Modulating the Excess of Affect: Morale in a State of 'Total War'," Ben Anderson poses this series of questions:

How to attend to, welcome, and care for indeterminacy, for affect's virtuality? How, in short, to realize the promise that is attached to affect? And how to simultaneously bear witness to forms of power that function through this indeterminacy, not by reducing it but by saturating or intensifying it? (162)

In reference to nationalism, and as these Canadian novels seem to suggest, its apocalyptic, complete destruction appears to be the solution to each of these questions to ensure the prosperity of civilization in a new world: nationalism must lose the ability - and the context - in which to weaponize affect to profit in the global capitalist system. In fact, these texts seem to take King's lead and promote a more communal 
cartography, one that dismantles the individualistic and capitalistic borders of nationalist entities.

\section{Notes:}

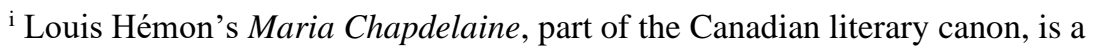
romance novel that features a young woman who must choose between two suitors, and with them between two lifestyles - the city or the country.

ii For detailed criticism of Atwood's thematic examination of Canadian literature, see in particular Mathews' "Survival and the Struggle in Canadian Literature" (1972-73) and Canadian Literature: Surrender or Revolution (1978), Daveys' "Atwood Walking Backwards" (1973) and "Surviving the Paraphrase: Thematic Criticism and its Alternatives" (1976), and Pivato's Contrasts: Comparative Essays on Italian-Canadian Writing (1985) and "Atwood's Survival: A Critique" (2015).

iii The colonial apocalypse for Indigenous peoples has also been discussed in the American context (see, for example, Lawrence Gross' "Storytelling and Cultural Survival in the Wake of an Apocalypse: The Case of the Anishinaabe" 2006) as well as in Australia (see, for instance, Claire G. Coleman's "Apocalypses are more than the stuff of fiction - First Nations Australians survived one" 2017).

${ }^{\text {iv }}$ For a more thorough study of apocalyptic affects and the Canadian literary imaginary in the twenty-first century, see "Theorizing the Apocalyptic Turn in the Literatures of Canada: Un/Veiling the Apocalyptic Direction in Affect Studies," my forthcoming chapter in All the Feels / Tous les sens: Affect and Writing in Canada / Affect et écriture au Canada, edited by Marie Carrière, Kit Dobson, and Ursula Moser (book in press 2020).

\section{Works Cited}

Ahmed, Sara. The Promise of Happiness. London: Duke UP, 2010.

Anderson, Ben. "Modulating the Excess of Affect: Morale in a State of 'Total War'." The Affect Theory Reader. Ed. Melissa Gregg and Gregory J. Seigworth. London: Duke UP, 2010. 161-185.

Atwood, Margaret. Survival: A Thematic Guide to Canadian Literature. 1972. Reprint. Toronto: House of Anansi P, 2012.

Berlant, Lauren. Cruel Optimism. London: Duke UP, 2011.

Coleman, Claire G. "Apocalypses are more than the stuff of fiction: First Nations Australians survived one." ABC NEWS. 7 Dec. 2017. Web. 29 Sep. 2020.

Cormier, Matthew. "Theorizing the Apocalyptic Turn in the Literatures of Canada: Un/Veiling the Apocalyptic Direction in Affect Studies." All the Feels / Tous les sens: Affect and Writing in Canada / Affect et écriture au Canada. Ed. Marie Carrière, Kit Dobson, and Ursula Moser. Edmonton: U of Alberta P, 2020. 3-22. 
Davey, Frank. “Atwood Walking Backwards.” Open Letter II. 5 (Summer 1973): 74-84.

---. "Surviving the Paraphrase: Thematic Criticism and Its Alternatives." Canadian Literature. 70 (1976): 5-13.

Davis, Tracy C. States of Emergency: Cold War Nuclear Civil Defense. London: Duke UP, 2007.

Derrida, Jacques. "On a Newly Arisen Apocalyptic Tone in Philosophy." Raising the Tone in Philosophy: Late Essays by Immanuel Kant, Transformative Critique by Jacques Derrida. Ed. Peter Fenves. Baltimore: Johns Hopkins UP, 1993. 117-171.

Dickner, Nicolas. Apocalypse for Beginners. Trans. Lazer Lederhendler. Toronto: Vintage Canada, 2010.

Dillon, Grace L. "Imagining Indigenous Futures." Walking the Clouds: An Anthology of Indigenous Science Fiction. Ed. Grace L. Dillon. Tucson, AZ: U of Arizona P, 2012. 1-12.

Goldman, Marlene. Rewriting Apocalypse in Canadian Fiction. Montreal: McGill UP, 2005.

Gregg, Melissa, and Gregory J. Seigworth. "An Inventory of Shimmers." The Affect Theory Reader. Ed. Melissa Gregg and Gregory J. Seigworth. London: Duke UP, 2010. 1-25.

Gross, Lawrence. "Storytelling and Cultural Survival in the Wake of an Apocalypse: The Case of the Anishinaabe." Public Lecture. U of California, Davis. 2006.

Hémon, Louis. Maria Chapdelaine. Paris: Le Temps, 1913.

Hutcheon, Linda. "The Politics of Representation." Signature: A Journal of Theory and Canadian Literature. 1. 1 (1989): 23-44.

King, Thomas. The Back of the Turtle. New York, NY: HarperCollins, 2014.

Massumi, Brian. "The Future Birth of the Affective Fact: The Political Ontology of Threat." The Affect Theory Reader. Ed. Melissa Gregg and Gregory J. Seigworth. London: Duke UP, 2010. 52-70.

Mathews, Robin. Canadian Literature: Surrender or Revolution. Toronto: Steel Rail Educational Pub, 1978.

---. "Survival and the Struggle in Canadian Literature." This Magazine Is About Schools. 1.4 (1972-73): 109-24.

Moodie, Susanna. Roughing It in The Bush: or, Life in Canada. New York: G.P. Putnam, 1852.

Pippin, Tina. Apocalyptic Bodies: The Biblical End of the World in Text and Image. Abingdon, Oxfordshire: Routledge, 1999.

Pivato, Joseph. "Atwood's Survival: A Critique." English-Canadian Writers. 2015. Web. 29 Sep. 2020.

---. Contrasts: Comparative Essays on Italian-Canadian Writing. Montreal: Guernica, 1985.

St. John Mandel, Emily. Station Eleven. New York, NY: HarperCollins, 2014.

Žižek, Slavoj. Living in the End Times. New York, NY: Verso, 2010. 